\begin{tabular}{lcl}
\hline Bentham open & The Open Respiratory Medicine \\
CrossMark & Journal \\
\hline
\end{tabular}

RESEARCH ARTICLE

\title{
Central Venous Oxygen Saturation as a Predictor of a Successful Spontaneous Breathing Trial from Mechanical Ventilation: A Prospective, Nested Case-Control Study
}

Ioannis Georgakas ${ }^{1,3,5}$, Afroditi K. Boutou ${ }^{1,2, *}$, Georgia Pitsiou ${ }^{1}$, Ioannis Kioumis ${ }^{4}$, Milly Bitzani ${ }^{3}$, Kristina Matei ${ }^{5}$, Paraskevi Argyropoulou ${ }^{1}$ and Ioannis Stanopoulos ${ }^{1}$

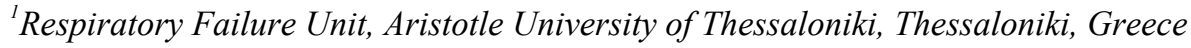

${ }^{2}$ Department of Respiratory Medicine, "G. Papanikolaou” Hospital, Thessaloniki, Greece

${ }^{3} 1$ st Intensive Care Unit, "G. Papanikolaou” Hospital, Thessaloniki, Greece

${ }^{4}$ Pulmonary Department, Aristotle University of Thessaloniki, Greece

${ }_{5}^{5}$ Intensive Care Unit, General Hospital of Veroia, Veroia, Greece

Received: November 24, 2017

Revised: January 22, 2018

Accepted: March 04, 2018

\section{Abstract:}

\section{Background:}

Weaning from mechanical ventilation is a key element in the care of critically ill patients, and Spontaneous Breathing Trial (SBT) is a crucial step in this procedure. This nested case-control study aimed to evaluate whether central oxygen saturation $\left(\mathrm{ScvO}_{2}\right)$ values and their changes could independently predict the SBT outcome among mechanically ventilated patients.

\section{Methods:}

A prospective cohort of patients who were mechanically ventilated for at least 48 hours and fulfilled the criteria of readiness to wean constituted the study population. All patients attempted a SBT and were then categorized in SBT success group and SBT failure group, based on a combination of criteria which indicated whether SBT was successful or not. Multivariate binary logistic regression analysis was utilized to indicate the independent predictors of SBT success, while the Receiver Operating Characteristic (ROC) curves were used to demonstrate the diagnostic accuracy of these independent predictors.

\section{Results:}

Seventy-seven patients $69(18-86)$ years old; $62.3 \%$ male) constituted the study population. SBT was successful among $63.6 \%$ of them. A decrease in $\mathrm{ScvO}_{2}$ values $\left(\Delta \mathrm{ScvO}_{2}\right)<4 \%$ between the beginning and the end of the trial independently predicted the successful outcome ( $\mathrm{OR}=18.278 ; 95 \% \mathrm{CI}=4.017-83.163)$, along with age, Hemoglobin concentration $(\mathrm{Hb})$ and arterial oxygen saturation $\left(\mathrm{SaO}_{2}\right)$. Diagnostic accuracy for $\Delta \mathrm{ScvO}_{2}$ alone $\left(\mathrm{ROC}\right.$ area=0.715) was slightly superior to that of either $\mathrm{SaO}_{2}(0.625)$ or $\mathrm{Hb}$ (0.685) to predict SBT success.

\section{Conclusion:}

$\mathrm{ScvO}_{2}$ is an independent predictor of the weaning outcome and its evaluation may further facilitate the accurate categorization among those patients who pass or fail the SBT.

Keywords: Central venous oxygen saturation, Spontaneous breathing trial, Weaning, Mechanical ventilation, Nested case-control study, Oxygen extraction ratio.

\footnotetext{
* Address correspondence to this author at the Department of Respiratory Medicine, "G. Papanikolaou" Hospital, Afroditi K. Boutou, Exohi, 57010, Thessaloniki, Greece; Tel: 00306946611433 ; E-mail: afboutou@yahoo.com
} 


\section{INTRODUCTION}

Weaning patients from mechanical ventilation are one of the key elements in the course of the treatment of critically ill patients and could represent up to $40 \%$ of the time that a patient spends on mechanical ventilation [1, 2]. A prolongation of mechanical weaning is associated with increased risk of complications, such as ventilator-associated pneumonia, tracheal injury, bleeding from digestive stress ulcers and sepsis [3 - 5], while early extubation and reintubation could result to nosocomial pneumonia and increased mortality $[6,7]$. Thus, identifying the optimal point when a patient can sustain spontaneous breathing is essential, but could be challenging.

In order to facilitate physicians in identifying the patients who are ready to wean from mechanical ventilation after the resolution of acute disease phase, a number of criteria have been set, in a two-step procedure [8], which begins with a trial of spontaneous breathing (SBT) via a T-tube. Since no single and consistent predictor has been found to accurately predict the SBT outcome $[9,10]$, the decision of a successful or not trial is based on a combination of another set of criteria evaluating the hemodynamic or not stability of the patient and the change of mental status, oxygenation and ventilatory efficiency during spontaneous breathing [8]. Previous data indicate that global tissue oxygenation is an important predictor of the weaning outcome $[11,12]$ and is associated, especially among patients who fail to wean, with the increased oxygen cost of breathing due to the strenuous working respiratory muscles [12]. Mixed venous oxygen saturation $\left(\mathrm{SvO}_{2}\right)$, which requires invasive measurements via right heart catheterization, and the easier to obtain central venous oxygen saturation $\left(\mathrm{ScvO}_{2}\right)$, are two indices closely associated with global tissue oxygenation; Nevertheless, their routine screening is currently not recommended as part of the evaluation of the SBT outcome. Although SvO2 and $\mathrm{ScvO} 2$ measurements have been previously studied in regards to several outcomes and in several patient populations [2, $13,14]$, data on the prognostic accuracy of $\mathrm{SvO}_{2}$ values, $\mathrm{ScvO}_{2}$ values and their changes on the weaning outcome, is currently limited $[2,15,16]$. Moreover, most of these studies were conducted in selected patient populations [2, 15] or aimed to investigate whether $\mathrm{ScvO}_{2}$ and $\mathrm{SvO}_{2}$ could predict the extubation outcome, which is the final and not the initial step of the weaning procedure $[2,16]$ and could be, thus, influence by several other factors not closely associated with tissue oxygenation, such as an inadequate cough or laryngeal edema [10].

To the author's knowledge, data on the clinical significance of $\mathrm{ScvO}_{2}$ as a potential predictor of the SBT outcome is currently scarce. Thus, we conducted a prospective study aiming to evaluate whether $\mathrm{ScvO}_{2}$ values and their changes between the initiation and the end of a thirty-minute long SBT could independently predict the outcome of this trial, in a general surgical and medical population of mechanically ventilated patients.

\section{MATERIAL AND METHODS}

\subsection{Study Population}

This is a prospective nested case-control study. All patients who were under mechanical ventilation for at least 48 hours in two medical Intensive Care Units (ICU) of "G. Papanikolaou” hospital between January 2012 and December 2012, were eligible for the study. Patients who were intubated for less than 48 hours, who had undergone an early tracheostomy (in less than 48 hours), who died before any weaning trials from mechanical ventilation were attempted and/or who did not have a central venous catheter, were excluded from final analysis; the rest constituted the final study population. All patients underwent a 30-minute long SBT before an attempt for extubation was undertaken and based on the outcome of the trial were then separated in two groups: the group of patients with successful SBT (cases) and the group of patients with SBT failure (controls). The Research Ethics Committee of the Aristotle University of Thessaloniki approved the study protocol and informed consent was taken either by the patients or their first-degree relatives.

\subsection{Study Measurements}

Demographic and anthropometric characteristics (gender, age, height, and weight), Acute Physiology and Chronic Health Evaluation (APACHE II) score at first 24hours of ICU stay, days on mechanical ventilation until the first weaning trial was conducted and the ICU admission diagnosis were recorded for all patients. Hemoglobin (Hb) and serum sodium $(\mathrm{Na})$, potassium $(\mathrm{K})$ and calcium $(\mathrm{Ca})$ concentrations were recorded just before the SBT, while arterial blood gases values (arterial oxygen partial pressure $\left(\mathrm{PaO}_{2}\right)$, arterial carbon dioxide partial pressure $(\mathrm{PaCO})$, $\mathrm{pH}$ and $\left.\mathrm{HCO}_{3}\right)$, arterial oxygen saturation $\left(\mathrm{SaO}_{2}\right), \mathrm{ScvO}_{2}$, respiratory frequency (f), Heart Rate (HR) and Systemic Systolic (SBP) and diastolic (DBP) blood pressure were measured at two time points: just before and after the 30 minute long 
SBT. The Oxygen Extraction Ratio $\left(\mathrm{O}_{2} \mathrm{ER}\right)$ was calculated by the equation: $\mathrm{O}_{2} \mathrm{ER}=\left(\mathrm{SaO}_{2}-\mathrm{ScvO}_{2}\right) / \mathrm{SaO}_{2}$ and was also recorded just before the beginning and at the end of the SBT. Moreover, the Rapid Shallow Breathing Index (RSBI), that is the respiratory frequency (f) to Tidal Volume $(\mathrm{Vt})$ ratio $(\mathrm{f} / \mathrm{Vt})$ was measured with a handheld Wright spirometer which was placed on the patient's endotracheal tube at the end of it (at 30 minutes), while the patient's Maximum Inspiratory Pressure (MIP) was also measured at the end of the SBT, using a manometer with a unidirectional valve.

\subsection{Study Procedures}

All patients were ventilated on Servo I, Servo 300 or Servo 900c (Siemens) ventilators and had a subclavian, femoral or an internal jugular central venous catheter placed; No patient had a Swan-Ganz catheter since its placement is not done during routine clinical practice. Every 24 hours all participants were assessed for readiness to wean by two intensivists, who decided to proceed on a 30 minute long SBT, based on published guidelines [8]. Criteria for readiness to wean included: 1) resolution of acute disease phase which resulted to intubation and mechanical ventilation, 2) adequate cough with not excessive bronchial secretions, 3) hemodynamic stability (no signs of myocardial ischemia, stable SBP (90-160 mmHg) with no or minimal vasoactive drugs (e.g. dopamine or dobutamine dosage $\leq 5 \mu \mathrm{g} / \mathrm{kg} / \mathrm{min}$ ) and $\mathrm{HR} \leq 140$ beats/min $), 4)$ adequate oxygenation $\left(\mathrm{PaO}_{2} \geq 60 \mathrm{mmHg}\right.$ with Fraction of Inspired Oxygen $\left[\mathrm{FiO}_{2}\right] \leq 40 \%$ or $\mathrm{PaO}_{2} / \mathrm{FiO}_{2}>150 \mathrm{mmHg}$; Positive End Expiratory Pressure [PEEP] $\leq 8 \mathrm{cmH}_{2} \mathrm{O}$; and normal (or close to patient's baseline) $\left.\mathrm{PaCO}_{2}\right)$, 5) adequate pulmonary function ( $\mathrm{MIP} \leq-20 \mathrm{~cm} \mathrm{H} \mathrm{H}_{2} \mathrm{O}$ and $\mathrm{f} \leq 35$ breaths/min), 6) no major electrolyte disorders and 7) adequate mentation (Glasgow Coma Scale $\geq 13$ ).

All patients who were found to be ready to wean were put on a T-piece with adequate oxygen flow in order $\mathrm{FiO}_{2}$ to be similar to that given during mechanical ventilation; the SBT lasted for 30 minutes. Study measurements which were conducted just before the SBT (including arterial and venous blood sampling), were completed while the patients were still on Pressure Support Mode of mechanical ventilation, while those which were conducted at the end of SBT were recorded after 30 minutes of spontaneous breathing on a T-piece.

The SBT was considered as a success or failure at 30 minutes, based on the Task Force criteria, that is both subjective indices and objective measurements. Failure criteria of SBT included: 1) agitation and anxiety, altered mental status, dyspnea, cyanosis and clinical evidence of increased respiratory effort, 2) hypoxemia and/or hypercapnia $\left(\mathrm{PaO}_{2}<60 \mathrm{mmHg}\right.$ or $\mathrm{SaO}_{2}<90 \%$ on $\mathrm{FiO}_{2} \geq 0.5 ; \mathrm{PaCO}_{2}>50 \mathrm{mmHg}$ or $\Delta \mathrm{PaCO}_{2}>8 \mathrm{mmHg} ; \mathrm{pH}<7.32$ or $\left.\left.\Delta \mathrm{pH}>0.07\right), 3\right)$ ineffective respiratory function (RSBI $>105$ breaths*min/L), and 4) hemodynamic complications (cardiac arrhythmias, tachycardia $[\mathrm{HR}>140$ beats $/ \mathrm{min}$ or $\Delta \mathrm{HR} \geq 20 \%$ ], hypertension [SBP $>180 \mathrm{mmHg}$ or $\Delta \mathrm{SBP} \geq 20 \%$ ] or hypotension $[\mathrm{SBP}<90 \mathrm{mmHg}]$ ) [8]. All patients who fulfilled the criteria of SBT success were then extubated.

\subsection{Statistical Analysis}

Statistical analysis was performed using the Predictive Analytics Software (PASW, SPSS Inc) Version 18. The Shapiro-Wilk test of normality was utilized to assess whether variables were normally distributed. Data are presented as mean $\pm 1 \mathrm{SD}$, median (minimum-maximum), or as \% percentages based on the normality or not of their distribution. Comparisons between cases and controls were conducted using the Chi-Square test for qualitative variables, while for quantitative variables either the Independent Samples Student's t-test or the Mann Whitney-U test was utilized, based on the distribution of their values. All variables which were found to be univariately associated with a successful SBT outcome were then entered into a multivariate stepwise binary logistic regression analysis model, in order independent predictors of SBT success to be identified. High intercorrelated values were opted out for further analysis and so was $\mathrm{f} / \mathrm{Vt}$ index, since all patients with $\mathrm{f} / \mathrm{Vt}>105$ were a priori grouped as having $\mathrm{SBT}$ failure. $\Delta \mathrm{ScvO}_{2} \%$ was calculated as $\left(\left(\mathrm{ScvO}_{2} \text { end-ScvO }{ }_{2} \text { start }\right) / \mathrm{ScvO}_{2} \text { start }\right)^{*} 100$. Its median value for the failure group was used as a potential threshold and multivariate analysis rerun with $\Delta \mathrm{ScvO}_{2}$ as a binary variable. A level of $\mathrm{p}<0.05$ was considered significant to identify independent predictors of SBT success. Odds Ratios (OR) with corresponding 95\% Confidence Intervals (CI) were reported for each predictor. Moreover, a Receiver Operating Characteristic (ROC) Curve was constructed for each SBT predictor, and the area under the curve was used as a visual index of the diagnostic accuracy of each one of them.

\section{RESULTS}

A total of 77 patients $(69(18-86)$ years old; $62.3 \%$ male) constituted the study population (Table 1). The main diagnosis of ICU entry were infections (such as pneumonia or abdominal infections) (32.5\%), major surgery (chest, abdominal, brain, vascular or orthopedic surgery) (39\%), cardiac arrest (3.9\%), trauma (9.1\%), acute respiratory failure (2.5\%), status epilepticus (3.9\%), burns (1.3\%), stroke (3.9\%) and intoxication (3.9\%). Overall, 49 patients $(63.6 \%)$ had 
a successful SBT, with the rest 28 (36.4\%) having a SBT failure. Patients who had a successful SBT were younger (66 (25) vs. 73.5 (11) years old; $p=0.024)$, while no other difference was noted between the groups in demographic and rest of baseline characteristics (Table 1).

Table 1. Baseline characteristics of the study population.

\begin{tabular}{|c|c|c|c|c|}
\hline Variable & Total population $(\mathrm{N}=77)$ & $\begin{array}{c}\text { SBT success } \\
(\mathrm{N} 1=49)\end{array}$ & \begin{tabular}{|c|} 
SBT failure \\
(N2=29)
\end{tabular} & $\mathbf{p}$ \\
\hline Age, yrs & $69(24)$ & $66(25)$ & $73.5(11)$ & 0.024 \\
\hline $\begin{array}{c}\text { Gender \% (n) } \\
\text {-male } \\
\text {-female }\end{array}$ & $\begin{array}{l}62.3(48) \\
37.7(29)\end{array}$ & $\begin{array}{l}70.8(34) \\
51.7(15)\end{array}$ & $\begin{array}{l}29.2(14) \\
48.3(14)\end{array}$ & 0.091 \\
\hline APACHE II score & $19.4 \pm 7$ & $19.1 \pm 7.3$ & $19.9 \pm 6.7$ & 0.639 \\
\hline $\begin{array}{c}\text { CVC placement } \%,(\mathbf{n}) \\
\text {-jugular } \\
\text {-subclavian } \\
\text {-femoral } \\
\end{array}$ & $\begin{array}{c}54.5(42) \\
9.1(7) \\
36.4(28)\end{array}$ & $\begin{array}{c}64.3(27) \\
57.1(4) \\
64.3(18)\end{array}$ & $\begin{array}{c}35.7(15) \\
42.9(3) \\
35.7(10)\end{array}$ & 0.932 \\
\hline Days on mechanical ventilation until first SBT & $4(4)$ & $4(4)$ & $4(4)$ & 0.542 \\
\hline
\end{tabular}
SBT: Spontaneous breathing trial CVC: central venous catheter

(Table 2) presents all measurements which were contacted just before and/or at the end of the SBT. Apart from Hb concentration, which was significantly lower among those who failed the SBT (8.9 (1.9) vs. 9.8 (2.2) $\mathrm{g} / \mathrm{dl}$; p=0.028), compared to those who succeeded, no difference was noted between the two groups, regarding measurements which were contacted just before the trial. On the contrary, by the end of it, the group of patients with successful SBT had higher $\mathrm{SaO}_{2}$ end (97.8 (2) vs. 97.5 (1) \%; $\left.\mathrm{p}=0.014\right)$, higher $\mathrm{ScvO}_{2}$ end (77.2 \pm 7.8 vs. $71.9 \pm 8.4 \%$; $\left.\mathrm{p}=0.007\right)$, a trend towards higher $\mathrm{PaO}_{2}$ end $(104.9 \pm 32$ vs. $91.3 \pm 27.7 \mathrm{~mm} \mathrm{Hg} ; \mathrm{p}=0.063)$, lower $\mathrm{O}_{2}$ ERend $(20.9 \pm 7.7$ vs. 25.4 $\pm 7.9 ; \mathrm{p}=0.020)$ and lower f/Vt index $(60 \pm 26.37$ vs. $106.2 \pm 48.3$; $<<0.001)$, compared to those with SBT failure.

The final multivariate model included age, $\mathrm{Hb}, \mathrm{SaO}_{2}$ end and $\mathrm{ScvO}_{2}$ end. $\mathrm{O}_{2}$ ERend was opted out due to high intercorrelation to $\mathrm{ScvO}_{2}$ end ( $\mathrm{r}=0.982$ ). $\mathrm{SaO}_{2}$ end, $\mathrm{Hb}$ concentration and $\mathrm{ScvO}_{2}$ end were positively associated, while age was negatively associated with SBT success (Table 3). (Fig. 1) presents ROC curves for $\mathrm{ScvO}_{2} \mathrm{end}, \mathrm{SaO}_{2} \mathrm{end}$ and $\mathrm{Hb}$ concentration for a successful SBT outcome, with an area under curve being $0.685,0.625$ and 0.629 for $\mathrm{ScvO}_{2}$ end, $\mathrm{SaO}_{2}$ end and $\mathrm{Hb}$ concentration, correspondingly. Median $\Delta \mathrm{ScvO}_{2} \%$ value for the SBT failure group was equal to $-4.2 \%$, so we rerun the multivariate regression analysis including the binary parameter $\Delta \mathrm{ScvO}_{2} \%(\geq 4 \%$ or $<4 \%)$ instead of $\mathrm{ScvO}_{2}$ end. A decrease of less than $4 \%$ in $\mathrm{ScvO}_{2}$ values between the beginning and the end of an SBT was also independently associated with a successful outcome $(\mathrm{OR}=18.278 ; 95 \% \mathrm{CI}=4.017-83.163, \mathrm{p}<0.001)$, along with age, $\mathrm{Hb}$ concentration and $\mathrm{SaO}_{2}$ end. The area under the curve for $\triangle \mathrm{ScvO} 2 \%$ in predicting a successful SBT was 0.712

Table 2. Parameters which were evaluated in the two groups just before and at the end of SBT.

\begin{tabular}{|c|c|c|c|c|}
\hline Variable & Total population $(\mathrm{N}=77)$ & $\begin{array}{l}\text { SBT success } \\
(\mathrm{N} 1=49)\end{array}$ & $\begin{array}{l}\text { SBT failure } \\
(\mathrm{N} 2=29)\end{array}$ & $\mathbf{p}$ \\
\hline$* \mathrm{Hb}, \mathrm{g} / \mathrm{dl}$ & $9.5(2.4)$ & $9.8(2.2)$ & $8.9(1.9)$ & 0.028 \\
\hline$* \mathrm{FiO}_{2}$ & $0.4(0.1)$ & $0.4(0.1)$ & $0.4(0.1)$ & 0.958 \\
\hline$* \mathrm{PaO}_{2} / \mathrm{FiO}_{2}$ & $273.3(145.3)$ & $280.1 \pm 95.7$ & $292.4 \pm 90.1$ & 0.601 \\
\hline *MIP, $\mathrm{cm} \mathrm{H}_{2}$ & $40(24)$ & $40(22)$ & $40(32)$ & 0.395 \\
\hline $\mathrm{SaO}_{2}$ start, $\%$ & $98(1.5)$ & $98(1.4)$ & $98(1.7)$ & 0.675 \\
\hline $\mathrm{SaO}_{2}$ end, $\%$ & $97.7(2)$ & $97.8(2)$ & $97.5(1)$ & 0.014 \\
\hline $\mathrm{ScvO}_{2}$ start, $\%$ & $75.6 \pm 8$ & $76 \pm 8.8$ & $74.9 \pm 6.6$ & 0.573 \\
\hline $\mathrm{ScvO}_{2}$ end, $\%$ & $75.3 \pm 8.4$ & $77.2 \pm 7.8$ & $71.9 \pm 8.4$ & 0.007 \\
\hline $\mathrm{PaO}_{2}$ start, $\mathrm{mm} \mathrm{Hg}$ & $109.4 \pm 27.7$ & $108.4 \pm 27.2$ & $111.1 \pm 29$ & 0.958 \\
\hline $\mathrm{PaO}_{2}$ end, $\mathrm{mm} \mathrm{Hg}$ & $98 \pm 31$ & $104.9 \pm 32$ & $91.3 \pm 27.7$ & 0.063 \\
\hline $\mathrm{pH}$ start & $7.43 \pm 0.04$ & $7.42 \pm 0.05$ & $7.43 \pm 0.04$ & 0.680 \\
\hline $\mathrm{pH}$ end & $7.42 \pm 0.04$ & $7.42 \pm 0.04$ & $7.42 \pm 0.04$ & 0.840 \\
\hline $\mathrm{HCO}_{3}$ start & $26.6 \pm 5.4$ & $26.6 \pm 5.5$ & $26.5 \pm 5.4$ & 0.967 \\
\hline $\mathrm{HCO}_{3}$ end & $27.1 \pm 5.9$ & $26.8 \pm 6.1$ & $27.5 \pm 5.6$ & 0.592 \\
\hline $\mathrm{PaCO}_{2}$ start, $\mathrm{mm} \mathrm{Hg}$ & $40.9 \pm 9.5$ & $41.2 \pm 10.2$ & $40.5 \pm 8.5$ & 0.744 \\
\hline $\mathrm{PaCO}_{2}$ end, $\mathrm{mm} \mathrm{Hg}$ & $42.3 \pm 11.2$ & $41.9 \pm 11.9$ & $43 \pm 10.1$ & 0.690 \\
\hline
\end{tabular}




\begin{tabular}{|c|c|c|c|c|}
\hline Variable & Total population $(\mathrm{N}=77)$ & $\begin{array}{c}\text { SBT success } \\
(\mathrm{N} 1=49)\end{array}$ & $\begin{array}{l}\text { SBT failure } \\
(\mathrm{N} 2=29)\end{array}$ & $\mathbf{p}$ \\
\hline $\mathrm{O}_{2}$ ER start & $22.7 \pm 8$ & $22.3 \pm 8.8$ & $23.3 \pm 6.6$ & 0.611 \\
\hline $\mathrm{O}_{2}$ ER end & $22.5 \pm 8$ & $20.9 \pm 7.7$ & $25.4 \pm 7.9$ & 0.020 \\
\hline HR start, beats $/ \mathrm{min}$ & $93.8 \pm 15.3$ & $95.1 \pm 14.6$ & $91.4 \pm 16.5$ & 0.307 \\
\hline HR end, beats/min & $99.4 \pm 16.1$ & $99.4 \pm 15.2$ & $99.5 \pm 17.8$ & 0.968 \\
\hline MAP start, $\mathrm{mm} \mathrm{Hg}$ & $93.3 \pm 13.1$ & $95.1 \pm 13.2$ & $90.1 \pm 12.6$ & 0.107 \\
\hline MAP end, $\mathrm{mm} \mathrm{Hg}$ & $95.1 \pm 14.7$ & $96.9 \pm 14.9$ & $91.8 \pm 13.9$ & 0.136 \\
\hline${ }^{\#} \mathrm{f} / \mathrm{Vt}$ & $77.6 \pm 42.7$ & $60 \pm 26.37$ & $106.2 \pm 48.3$ & $<0.001$ \\
\hline
\end{tabular}

SBT: Spontaneous breathing Trial; $\mathrm{Hb}$ : hemoglobin concentration; $\mathrm{FiO}_{2}$ : Fraction of Inspired Oxygen; PaO ${ }_{2}$ : arterial oxygen partial pressure; MIP: maximum inspiratory pressure; Start: measured just before the beginning of the SBT; End: measured at the end of SBT; SaO ${ }_{2}$ : arterial oxygen saturation; $\mathrm{ScvO}_{2}$ : central venous oxygen saturation; $\mathrm{HCO} 3$ : bicarbonate anion; $\mathrm{PaCO}_{2}$ : arterial carbon dioxide partial pressure; $\mathrm{O}_{2}$ ER: Oxygen extraction ratio; HR: heart rate; MAP: mean systemic arterial blood pressure

* Measured only once, just before SBT initiation

${ }^{*}$ Measured only once, at the end of SBT

Table 3. Multivariate predictors of SBT successful outcome.

\begin{tabular}{|c|c|c|c|}
\hline Variable & OR & 95\% CI & p \\
\hline $\mathrm{ScvO}_{2}$ end $(\%)$ & 1.122 & $1.005-1.257$ & 0.041 \\
\hline $\mathrm{SaO}_{2}$ end(\%) & 1.405 & $0.041-1.897$ & 0.026 \\
\hline Age $(\mathrm{y})$ & 0.961 & $1.080-2.221$ & 0.999 \\
\hline $\mathrm{Hb}(\mathrm{g} / \mathrm{dl})$ & 1.549 & 0.017 \\
\hline
\end{tabular}

$\mathrm{Hb}$ : hemoglobin concentration; $\mathrm{SaO}_{2}$ : arterial oxygen saturation; $\mathrm{ScvO}_{2}$ : central venous oxygen saturation

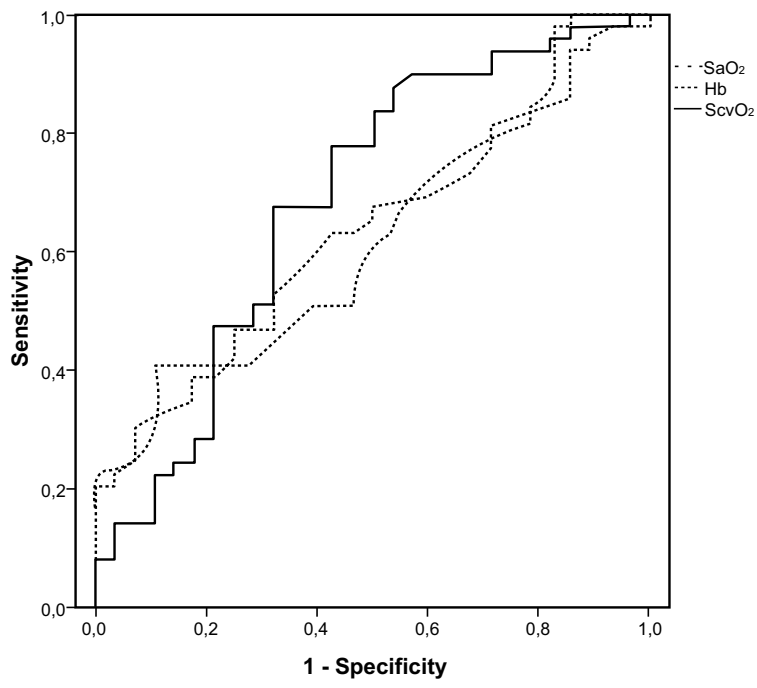

Fig. (1). ROC curves for $\mathrm{Hb}$ concentration, $\mathrm{SaO}_{2}$ (at the end of the SBT) and $\mathrm{ScvO}_{2}$ (at the end of the SBT) for predicting a successful SBT outcome.

\section{DISCUSSION}

In this prospective, nested case-control study we indicated that $\mathrm{ScvO}_{2}$ end is an independent predictor of SBT outcome, with a decrease of $\mathrm{ScvO}_{2}<4 \%$ being associated with SBT success. It is well-known that the characterization of a SBT as success or failure is normally based on a combination of subjective criteria and objective indices measured at the end of the 30 minute trial, according to guidelines, which do not include the evaluation of any $\mathrm{ScvO}_{2}$ values. However, our study confirms that $\mathrm{ScvO}_{2}$ end as a single index is independently associated with a positive outcome and although its diagnostic accuracy was moderate $\left(68.5 \%\right.$ for $\mathrm{ScvO}_{2}$ and $71.5 \%$ for $\left.\Delta \mathrm{ScvO}_{2}\right)$, it was slightly superior to that of $\mathrm{SaO}_{2}$, which is a routinely screened parameter.

According to the Fick principle, oxygen uptake $\left(\mathrm{VO}_{2}\right)$ depends on oxygen delivery $\left(\mathrm{DO}_{2}\right)$ and $\mathrm{O}_{2}$ ER $[17,18]$. This classic equation could be reformulated as a function of $\mathrm{SvO}_{2}$, indicating that the four components which are associated 
with $\mathrm{SvO}_{2}$ values are Cardiac Output (CO), $\mathrm{Hb}$ concentration, $\mathrm{VO}_{2}$ values and $\mathrm{SaO}_{2}$ values; However, the relationship between $\mathrm{SvO}_{2}$ and its components are not equivalent and not necessarily linear [19]. In a previous study where the relationship between $\mathrm{SvO}_{2}$ and $\mathrm{CO}$ was modeled using a standard population of 1000 ICU patients, the curve between $\mathrm{CO}$ and $\mathrm{SvO}_{2}$ was non-linear and $\mathrm{CO}$ was an important but not the predominant component of $\mathrm{SvO}_{2}$, except when very low [19]. In any case, $\mathrm{SvO}_{2}$ seems to be a variable that passively follows the regulation of its components so that for any change in $\mathrm{VO}_{2}$ needs, the tissue oxygenation represents the final adjustment between $\mathrm{O}_{2}$ delivery and uptake and determines the change in $\mathrm{SvO}_{2}$ [19]. Previously Jubran et al [11] utilized $\mathrm{SvO}_{2}$ monitoring in order to assess cardiovascular performance and global tissue oxygenation during the weaning process; In this study the group of patients who failed weaning established a progressive decrease in $\mathrm{SvO}_{2}$ values, compared to the rest, probably reflecting the increased $\mathrm{O}_{2}$ ER of respiratory muscles [11, 20]. According to Zakynthinos et al [12], in mechanically ventilated patients who failed to wean and presented with increased oxygen consumption, this was met by an increased tissue $\mathrm{O}_{2}$ ER and was reflected by a drop in $\mathrm{SvO}_{2}$ values, confirming the association between $\mathrm{SvO}_{2}$ and tissue oxygen delivery and consumption.

Previous studies have assessed the utility of $\mathrm{SvO}_{2}, \mathrm{ScvO}_{2}$ or their changes during weaning procedures. Among ten postoperative coronary artery bypass graft patients, Cason et al indicated that $\mathrm{SvO}_{2}$ was an important predictor of weaning, since weaning failure was associated with a drop of $\mathrm{SvO}_{2}$ of over $60 \%$ [15]. However the study size was minimal and the patient population was selected. In another selected population of postoperative coronary artery bypass graft patients, Armaganidis and Dhainaut [21] demonstrated that $\mathrm{SvO}_{2}>60 \%$ was the best weaning success predictor and it depended on $\mathrm{O}_{2}$ ER measurements. More recent studies concluded that change of $\mathrm{ScvO}_{2}$ during SBT was the only independent predictor of weaning from mechanical ventilation among patients who passed the first step of a two-step weaning procedure [16] and among difficult-to-wean patients [2]. In these studies, a drop of more than 4.5\% [16] or 5\% [2] in $\mathrm{ScvO}_{2}$ values, was associated with failure to wean from mechanical ventilation. Both protocols, though, investigated not whether $\mathrm{ScvO}_{2}$ is an index of a successful SBT, like in our study, but whether it is as a predictor of the extubation outcome within the following 48 hours. Nevertheless, laryngeal edema, low muscle endurance and inability to clear secretions are only some of the several potential causes of re-intubation, which are not directly associated to oxygen consumption and utilization, so these results may be, to an extent, difficult to explain.

In the current study, $\mathrm{Hb}$ was also independently associated with SBT outcome and had a similar diagnostic accuracy to $\mathrm{ScvO}_{2}$ values. In a large retrospective study conducted by Lai YC et al. [22]. Hb concentration was positively associated with a successful weaning, among difficult-to-wean patients, while in another smaller cohort lower Hb levels were associated with extubation failure [23], confirming our findings. The oxygen-carrying capacity of the blood depends directly on the level of $\mathrm{Hb}$ [24], and in normal individuals, $15 \mathrm{~g} / \mathrm{dl}$ of $\mathrm{Hb}$ carry approximately $21 \mathrm{ml}$ of oxygen per $100 \mathrm{ml}$ of blood [25]. In these subjects, a $3 \mathrm{~g} / \mathrm{dl}$ decrease in $\mathrm{Hb}$ levels would result in a reduction of the total oxygen-carrying capacity by $4 / 100 \mathrm{ml}$; this effect might be even more intense among patients with respiratory failure since $\mathrm{Hb}$ saturation is usually abnormal [26]. Under this scope, the reduction in oxygen-carrying capacity might further impede the aerobic metabolism of respiratory muscles, resulting in respiratory inefficiency and weaning failure.

$\mathrm{SaO}_{2}$ was also identified as an independent predictor of SBT success. This result comes to an agreement with previous data which indicated that an integrative index comprising $\mathrm{SaO}_{2}$ had a higher diagnostic accuracy in predicting the weaning outcome than other traditional indices [27]. When the arterial oxygen content is low, the diffusion gradient of oxygen from the blood to the mitochondria decreases more rapidly, potentially leading respiratory muscles to early anaerobic metabolism [26]. Surprisingly, the $\mathrm{PaO}_{2}$ end could not discriminate between the two groups in our study, neither at the beginning nor at the end of the trial, confirming the findings of similar studies in the field [2, 16]. Traditionally, the $\mathrm{PaO}_{2} / \mathrm{FiO}_{2}$ ratio has been used to identify patient populations ready to wean from mechanical ventilation [28 - 30]; Nevertheless, whether the diagnostic accuracy of $\mathrm{PaO}_{2}$ as a single index is similar to that of oxygen tension as part of composite indices remains to be investigated in the future.

The current study carries its strengths and limitations. Its prospective design minimized missing data and recall bias, while the inclusion of a general medical and surgical population allows for the generalizability of the results. Moreover, the same medical team evaluated readiness to wean and the SBT outcome, using similar criteria, so methodological bias, such as the ones that could be encountered in multi-center studies have been minimized. Although the sample size is relatively small, it is comparable to other similar studies in the field [2, 23]. A limitation of the study is that several weaning indices, such as airway occlusion pressure (P0.1), the P0.1/MIP ratio [27], and the integrative weaning index (static compliance of the respiratory system-arterial oxygen saturation/f/vt index) [31] have not been tested; However, 
the aim of the study was to investigate whether the diagnostic accuracy of $\mathrm{ScvO}_{2}$ in predicting the SBT outcome was similar to the one of other parameters which are routinely used for patient assessment, according to guidelines. Another limitation is that no hemodynamic measurements to assess $\mathrm{CO}$ were conducted in the patient cohort, nor we obtained any measurements of $\mathrm{SvO}_{2}$, due to the limited use of right heart catheterization; However, previous studies [32 - 34] demonstrated adequate correlation between $\mathrm{ScvO}_{2}$ and $\mathrm{SvO}_{2}$, especially among patients who are not in shock, while the costs and the potential risks of right heart catheterization make this technique less feasible in every-day clinical practice. Furthermore, most of the impact of $\mathrm{CO}$ on $\mathrm{SvO} 2$ measurements is evident when CO values are low [19]; Since none of the patients was hemodynamically unstable when SBT was attempted, we could hypothesize that measuring CO would not have changed the results. Finally, $\mathrm{VO}_{2}$ was not directly measured and, thus, increase of $\mathrm{VO}_{2}$ due to elevated respiratory muscle activity among patients who presented with lower $\mathrm{ScvO}_{2}$ can only be hypothesized; future studies utilizing indirect calorimetry through a mouthpiece could provide further information on this proposed association.

In summary, in this prospective nested case-control study conducted in a general ICU population, a $\mathrm{ScvO}_{2}$ drop of at least $4 \%$ was independently associated with failure to wean from mechanical ventilation, along with $\mathrm{Hb}$ concentration, $\mathrm{SaO}_{2}$, and age. Judging whether the SBT is successful or not, in order to proceed to extubation, is depended not on a single index but on a combination of several objectively measured and clinically evaluated parameters. Whether adding the routine evaluation of $\mathrm{ScvO}_{2}$ in this algorithm might improve the ability to correctly identify those patients who could safely proceed to extubation or not, remains to be tested in large prospective trials in the future.

\section{CONCLUSION}

$\mathrm{ScvO}_{2}$ is an independent predictor of the weaning outcome; a drop of at least $4 \%$ from its baseline values was associated with failure to wean from mechanical ventilation. More prospective studies are needed in order to investigate whether its systematic evaluation might further facilitate the accurate identification of those able to wean from mechanical ventilation.

\section{LIST OF ABBREVIATIONS IN ALPHABETICAL ORDER}

\begin{tabular}{|c|c|c|}
\hline APACHE & $=$ & Acute Physiology and Chronic Health Evaluation \\
\hline $\mathbf{C a}$ & $=$ & Calcium \\
\hline CI & $=$ & Confidence Interval \\
\hline CO & $=$ & Cardiac Output \\
\hline DBP & $=$ & Diastolic Blood Pressure \\
\hline $\mathbf{D O}_{2}$ & $=$ & Oxygen Delivery \\
\hline f & $=$ & Respiratory Frequency \\
\hline $\mathrm{FiO}_{2}$ & $=$ & Fraction of Inspired Oxygen \\
\hline $\mathbf{H b}$ & $=$ & Hemoglobin Concentration \\
\hline $\mathrm{HCO3}$ & $=$ & Bicarbonate Anion \\
\hline HR & $=$ & Heart Rate \\
\hline ICU & $=$ & Intensive Care Unit \\
\hline $\mathbf{K}$ & $=$ & Potassium \\
\hline MIP & $=$ & Maximum Inspiratory Pressure \\
\hline $\mathbf{N a}$ & $=$ & Sodium \\
\hline OR & $=$ & Odds Ratio \\
\hline $\mathbf{O}_{2} \mathbf{E R}$ & $=$ & Oxygen Extraction Ratio \\
\hline PEEP & $=$ & Positive End Expiratory Pressure \\
\hline RSBI & $=$ & Rapid Swallow Breathing Index \\
\hline P0.1 & $=$ & Airway Occlusion Pressure \\
\hline $\mathrm{PaCO} 2$ & $=$ & Arterial Carbon Dioxide Partial Pressure \\
\hline $\mathrm{PaO}_{2}$ & $=$ & Arterial Oxygen Partial Pressure \\
\hline ROC & $=$ & Receiver Operating Characteristic \\
\hline $\mathrm{SaO}_{2}$ & $=$ & Arterial Oxygen Saturation \\
\hline
\end{tabular}




$\begin{array}{lll}\mathbf{S B P} & = & \text { Systemic Systolic Blood Pressure } \\ \mathbf{S B T} & = & \text { Spontaneous Breathing Trial } \\ \mathbf{S c v O}_{2} & = & \text { Central Venous Oxygen Saturation } \\ \mathbf{S v O}_{2} & = & \text { Mixed Venous Oxygen Saturation } \\ \mathbf{V O}_{2} & = & \text { Oxygen Uptake } \\ \mathbf{V t} & = & \text { Tidal Volume } \\ \Delta \mathbf{S c v O 2} & & \text { Change in } \mathrm{ScvO}_{2} \text { values between the beginning and the end of SBT }\end{array}$

\section{ETHICS APPROVAL AND CONSENT TO PARTICIPATE}

The Research Ethics Committee of the Aristotle University of Thessaloniki approved the study protocol (IRB number 2/4-4-2011).

\section{HUMAN AND ANIMAL RIGHTS}

No Animals were used in this research. All human research procedures followed were in accordance with the ethical standards of the committee responsible for human experimentation (institutional and national), and with the Helsinki Declaration of 1975 , as revised in 2008 .

\section{CONSENT FOR PUBLICATION}

Informed consent was taken either by the patients or their first-degree relatives.

\section{CONFLICT OF INTEREST}

The authors declare no conflict of interest, financial or otherwise.

\section{ACKNOWLEDGEMENTS}

We would like to acknowledge the nursing stuff of both ICU's for its valuable assistant during the weaning and extubation procedures of the patients.

\section{REFERENCES}

[1] MacIntyre NR, Cook DJ, Ely EW Jr, et al. Evidence-based guidelines for weaning and discontinuing ventilatory support: a collective task force facilitated by the american college of chest physicians; the american association for respiratory care; and the american college of critical care medicine. Chest 2001; 120(6)(Suppl.): 375S-95S. [http://dx.doi.org/10.1378/chest.120.6_suppl.375S] [PMID: 11742959]

[2] Teixeira C, da Silva NB, Savi A, et al. Central venous saturation is a predictor of reintubation in difficult-to-wean patients. Crit Care Med 2010; 38(2): 491-6.

[http://dx.doi.org/10.1097/CCM.0b013e3181bc81ec] [PMID: 19789441]

[3] Esteban A, Frutos F, Tobin MJ, et al. A comparison of four methods of weaning patients from mechanical ventilation. N Engl J Med 1995; 332(6): 345-50.

[http://dx.doi.org/10.1056/NEJM199502093320601] [PMID: 7823995]

[4] Torres A, Serra-Batlles J, Ros E, et al. Pulmonary aspiration of gastric contents in patients receiving mechanical ventilation: the effect of body position. Ann Intern Med 1992; 116(7): 540-3.

[http://dx.doi.org/10.7326/0003-4819-116-7-540] [PMID: 1543307]

[5] Epstein SK, Ciubotaru RL, Wong JB. Effect of failed extubation on the outcome of mechanical ventilation. Chest 1997; 112(1): 186-92. [http://dx.doi.org/10.1378/chest.112.1.186] [PMID: 9228375]

[6] Esteban A, Alía I, Tobin MJ, et al. Effect of spontaneous breathing trial duration on outcome of attempts to discontinue mechanical ventilation. Am J Respir Crit Care Med 1999; 159(2): 512-8. [http://dx.doi.org/10.1164/ajrccm.159.2.9803106] [PMID: 9927366]

[7] Vallverdú I, Calaf N, Subirana M, Net A, Benito S, Mancebo J. Clinical characteristics, respiratory functional parameters, and outcome of a two-hour T-piece trial in patients weaning from mechanical ventilation. Am J Respir Crit Care Med 1998; 158(6): 1855-62. [http://dx.doi.org/10.1164/ajrccm.158.6.9712135] [PMID: 9847278]

[8] Boles JM, Bion J, Connors A, et al. Weaning from mechanical ventilation. Eur Respir J 2007; 29(5): 1033-56. [http://dx.doi.org/10.1183/09031936.00010206] [PMID: 17470624]

[9] Meade M, Guyatt G, Cook D, et al. Predicting success in weaning from mechanical ventilation. Chest 2001; 120(6)(Suppl.): 400S-24S. [http://dx.doi.org/10.1378/chest.120.6_suppl.400S] [PMID: 11742961] 
[10] Boutou AK, Abatzidou F, Tryfon S, et al. Diagnostic accuracy of the rapid shallow breathing index to predict a successful spontaneous breathing trial outcome in mechanically ventilated patients with chronic obstructive pulmonary disease. Heart Lung 2011; 40(2): 105-10. [http://dx.doi.org/10.1016/j.hrtlng.2010.02.002] [PMID: 20561873]

[11] Jubran A, Mathru M, Dries D, Tobin MJ. Continuous recordings of mixed venous oxygen saturation during weaning from mechanical ventilation and the ramifications thereof. Am J Respir Crit Care Med 1998; 158(6): 1763-9. [http://dx.doi.org/10.1164/ajrccm.158.6.9804056] [PMID: 9847265]

[12] Zakynthinos S, Routsi C, Vassilakopoulos T, et al. Differential cardiovascular responses during weaning failure: effects on tissue oxygenation and lactate. Intensive Care Med 2005; 31(12): 1634-42.

[http://dx.doi.org/10.1007/s00134-005-2699-9] [PMID: 16247624]

[13] Williams J, McLean A, Ahari J, et al. Decreases in mixed venous Blood $\mathrm{O}_{2}$ saturation in cardiac surgery patients following extubation. J Intensive Care Med 2017; 885066617741435. Epub ahead of print [PMID: 29141527]

[14] Wittayachamnankul B, Chentanakij B, Sruamsiri K, Chattipakorn N. The role of central venous oxygen saturation, blood lactate, and central venous-to-arterial carbon dioxide partial pressure difference as a goal and prognosis of sepsis treatment. J Crit Care 2016; 36: 223-9. [http://dx.doi.org/10.1016/j.jcrc.2016.08.002] [PMID: 27566006]

[15] Cason CL, DeSalvo SK, Ray WT. Changes in oxygen saturation during weaning from short-term ventilator support after coronary artery bypass graft surgery. Heart Lung 1994; 23(5): 368-75.

[PMID: 7989205]

[16] Shalaby MA, Alsagheir MM, Salama AM, et al. Central venous oxygen saturation as a predictor of the outcome of weaning from mechanical ventilation. Journal of Education and Practice 2014; 5(7) ISSN 2222-288X

[17] Reinhart K, Kuhn HJ, Hartog C, Bredle DL. Continuous central venous and pulmonary artery oxygen saturation monitoring in the critically ill. Intensive Care Med 2004; 30(8): 1572-8. [http://dx.doi.org/10.1007/s00134-004-2337-y] [PMID: 15197435]

[18] Silance PG, Simon C, Vincent JL. The relation between cardiac index and oxygen extraction in acutely ill patients. Chest 1994; 105(4): $1190-7$.

[http://dx.doi.org/10.1378/chest.105.4.1190] [PMID: 8162748]

[19] Squara P. Central venous oxygenation: when physiology explains apparent discrepancies. Crit Care 2014; $18(6): 579$. [http://dx.doi.org/10.1186/s13054-014-0579-9] [PMID: 25407250]

[20] Tobin MJ, Jubran A. Weaning from mechanical ventilation.Principles and Practice of Mechanical Ventilation. 2nd ed. New York: McGrawHill 2006; pp. 1185-220.

[21] Armaganidis A, Dhainaut JF. [Weaning from artificial respiration: value of continuous monitoring of mixed venous oxygen saturation]. Ann Fr Anesth Reanim 1989; 8(6): 708-15. [English Abstract]. [http://dx.doi.org/10.1016/S0750-7658(89)80196-0] [PMID: 2633669]

[22] Lai YC, Ruan SY, Huang CT, Kuo PH, Yu CJ. Hemoglobin levels and weaning outcome of mechanical ventilation in difficult-to-wean patients: a retrospective cohort study. PLoS One 2013; 8(8): e73743. [http://dx.doi.org/10.1371/journal.pone.0073743] [PMID: 24015310]

[23] Boniatti VM, Boniatti MM, Andrade CF, et al. The modified integrative weaning index as a predictor of extubation failure. Respir Care 2014; 59(7): 1042-7. [http://dx.doi.org/10.4187/respcare.02652] [PMID: 24282317]

[24] Cote C, Zilberberg MD, Mody SH, Dordelly LJ, Celli B. Haemoglobin level and its clinical impact in a cohort of patients with COPD. Eur Respir J 2007; 29(5): 923-9.

[http://dx.doi.org/10.1183/09031936.00137106] [PMID: 17251227]

[25] Culver BH. Physiology.Comprehensive Respiratory Medicine. 1st ed. St Louis: Mosby Inc 1999; pp. 89-150.

[26] Boutou AK, Stanopoulos I, Pitsiou GG, et al. Anemia of chronic disease in chronic obstructive pulmonary disease: a case-control study of cardiopulmonary exercise responses. Respiration 2011; 82(3): 237-45. [http://dx.doi.org/10.1159/000326899] [PMID: 21576921]

[27] Nemer SN, Barbas CS, Caldeira JB, et al. A new integrative weaning index of discontinuation from mechanical ventilation. Crit Care 2009; 13(5): R152.

[http://dx.doi.org/10.1186/cc8051] [PMID: 19772625]

[28] Suematsu Y, Sato H, Ohtsuka T, Kotsuka Y, Araki S, Takamoto S. Predictive risk factors for pulmonary oxygen transfer in patients undergoing coronary artery bypass grafting. Jpn Heart J 2001; 42(2): 143-53. [http://dx.doi.org/10.1536/jhj.42.143] [PMID: 11384075]

[29] Todorova L, Temelkov A. Weaning from long-term mechanical ventilation: a nonpulmonary weaning index. J Clin Monit Comput 2004; 18(4): 275-81. [http://dx.doi.org/10.1007/s10877-005-2221-5] [PMID: 15779839]

[30] Bilello JF, Davis JW, Cagle KM, Kaups KL. Predicting extubation failure in blunt trauma patients with pulmonary contusion. J Trauma Acute Care Surg 2013; 75(2): 229-33. 
[http://dx.doi.org/10.1097/TA.0b013e3182946649] [PMID: 23823613]

[31] Nemer SN, Barbas CS. Predictive parameters for weaning from mechanical ventilation. J Bras Pneumol 2011; 37(5): 669-79. t [http://dx.doi.org/10.1590/S1806-37132011000500016] [PMID: 22042401]

[32] Vallet B, Wiel E, Lebuffe G. Resuscitation from circulatory shock.Textbook of Critical Care. 5th ed. Philadelphia: Elsevier Saunders 2005; pp. $905-10$.

[33] Sandham JD, Hull RD, Brant RF, et al. A randomized, controlled trial of the use of pulmonary-artery catheters in high-risk surgical patients. N Engl J Med 2003; 348(1): 5-14.

[http://dx.doi.org/10.1056/NEJMoa021108] [PMID: 12510037]

[34] Chawla LS, Zia H, Gutierrez G, Katz NM, Seneff MG, Shah M. Lack of equivalence between central and mixed venous oxygen saturation. Chest 2004; 126(6): 1891-6.

[http://dx.doi.org/10.1378/chest.126.6.1891] [PMID: 15596689]

(C) 2018 Georgakas et al.

This is an open access article distributed under the terms of the Creative Commons Attribution 4.0 International Public License (CC-BY 4.0), a copy of which is available at: (https:/creativecommons.org/licenses/by/4.0/legalcode). This license permits unrestricted use, distribution, and reproduction in any medium, provided the original author and source are credited. 